\title{
THE ROLE OF ALERT PATHOGENS IN BACTERIAL DISEASES IN PATIENTS HOSPITALIZED AT THE DEPARTMENT OF PULMONARY DISEASES AND TUBERCULOSIS, PUBLIC CLINICAL HOSPITAL NO. 3 IN ZABRZE IN 2008-2012
}

\author{
ROLA PATOGENÓW ALARMOWYCH W CHOROBACH BAKTERYJNYCH \\ U PACJENTÓW HOSPITALIZOWANYCH W KATEDRZE I KLINICE CORÓB PŁUC \\ I GRUŹLICY SAMODZIELNEGO PUBLICZNEGO SZPITALA KLINICZNEGO NR 3 \\ W ZABRZU W LATACH 2008-2012
}

\author{
Medical University of Silesia in Katowice, Poland \\ ${ }^{1}$ Department of Microbiology and Immunology, School of Medicine with the Division of Dentistry in Zabrze, \\ ${ }^{2}$ Department of Pulmonary Diseases and Tuberculosis, \\ Śląski Uniwersytet Medyczny w Katowicach \\ ${ }^{1}$ Katedra i Zakład Mikrobiologii i Immunologii, \\ Wydział Lekarski z Oddziałem Lekarsko-Dentystycznym w Zabrzu, \\ ${ }^{2}$ Klinika Chorób Płuc i Gruźlicy,
}

\begin{abstract}
BACKGROUND. The current public health problem is the increasing bacterial resistance to antibiotics. Microorganisms isolated from infections are more often non-susceptible to most available drugs. The microorganisms producing resistance mechanisms have been classified as so called alert pathogens.

METHODS. We performed a total number of 3810 tests of bronchoalveolar lavage and sputum of patients hospitalized for respiratory diseases at the Department of Pulmonary Diseases and Tuberculosis at Public Clinical Hospital No 3 in Zabrze (Poland). The research was performed in the microbiological laboratory of the Department of Microbiology and Immunology in Zabrze, Medical University of Silesia in Katowice, Poland. The analysis included Gram-positive and Gram-negative alert species strains.

RESULTS. In the period of five years, 144 strains of alert microorganisms have been isolated. The percentage of Gramnegative alert pathogens producing ESBL and KPC increased. MRSA, Steptococcus pneumoniae and Streptococcus pyogenes have been found to be the most often present among Gram-positive alert microorganisms. The lowest value of cultured alert pathogens $(3.9 \%)$ was noted in 2008, whereas the highest (16.5\%) in 2011. Gram-positive alert microorganisms showed resistance to macrolides and lincosamides, however, Gram-negative alert microorganisms showed the highest percentage of resistance to penicillins, penicillins with inhibitors and cephalosporins.

CONCLUSIONS. Our work has shown that over the period 2008-2012 an increased percentage of Gramnegative and Gram-positive alert microorganisms was observed.
\end{abstract}

Key words: alert pathogens, antibiotics, bacterial infections, resistant strains

\section{STRESZCZENIE}

WSTĘP. Obecnym problemem zdrowia publicznego jest narastająca oporność bakterii na antybiotyki. Mikroorganizmy izolowane z zakażeń są coraz częściej niewrażliwe na wiele dostępnych leków. Drobnoustroje, które posiadają szczególnie niebezpieczne mechanizmy oporności zaliczono do tzw. patogenów alarmowych.

METODY. Wykonano łącznie 3810 badań popłuczyn oskrzelowych oraz próbek plwociny u pacjentów przebywających na oddziale Kliniki Chorób Płuc i Gruźlicy Publicznego Szpitala Klinicznego nr 3 w Zabrzu. Badania przeprowadzono w Laboratorium Mikrobiologicznym Katedry i Zakładu Mikrobiologii i Immunologii w Zabrzu, Śląskiego Uniwersytetu Medycznego w Katowicach. Analiza obejmowała szczepy alarmowe Gram-dodatnie i Gram-ujemne.

WYNIKI. W okresie pięciu lat wyizolowano 144 szczepy patogenów alarmowych. Wzrósł odsetek bak-

(C) National Institute of Public Health - National Institute of Hygiene / Narodowy Instytut Zdrowia Publicznego - Państwowy Zakład Higieny 
terii Gram-ujemnych wytwarzających mechanizmy oporności typu ESBL i KPC. Wśród Gram-dodatnich mikroorganizmów najczęściej występował MRSA, Streptococcus pneumoniae i Streptococcus pyogenes. Najniższy odsetek patogenów alarmowych $(3,9 \%)$ zanotowano w roku 2008, natomiast najwyższy $(16,5 \%)$ w 2011. Drobnoustroje alarmowe Gram-dodatnie w badanym okresie cechowała oporność w stosunku do makrolidów i linkozamidów. Natomiast drobnoustroje alarmowe Gram-ujemne wykazywały najwyższy odsetek oporności $\mathrm{w}$ stosunku do penicylin, penicylin $\mathrm{z}$ inhibitorami oraz cefalosporyn. WNIOSKI. Wyniki naszych badań pokazują, iż w latach 2008-2012 zaobserwowano wzrost liczby Gram-ujemnych i Gram-dodatnich szczepów patogenów alarmowych.

Słowa kluczowe: patogeny alarmowe, antybiotyki, zakażenia bakteryjne, szczepy oporne

\section{INTRODUCTION}

The resistance to antibiotics is a very serious and growing public health problem. Microorganisms isolated from infections, which are resistant to most, and sometimes even to all available drugs, can be observed more and more often. They are referred to as 'alert pathogens' (1-2). A problem appears when microorganisms which are sensitive to antibiotics become resistant to them, which results from the process of horizontal exchange of genetic material between different strains of the species and even between species. The list of alert pathogens is specified in Polish Law Gazette No. 294 - 17195 - item. 1741 of 23 December 2011 (3). The most dangerous are methicyllin-resistant Staphylococcus aureus (MRSA), enterococci resistant to vancomycin (VRE), multidrug resistant non-fermenting strains Pseudomonas aeruginosa and Acinetobacter sp., strains of Enterobacteriaceae producing beta-lactamases with an extended substrate spectrum (ESBL) and producing carbapenemases: metallo-beta-lactamases (MBL), beta-lactamases with carbapenemase activity (Klebsiella pneumoniae carbapenemase, KPC) or OXA-48 (4). Strains producing beta-lactamases of ESBL, MBL and cephalosporinases (Amp C) types are especially difficult to control.

In the mid-1990s there were identified enzymes hydrolyzing broad spectrum of beta-lactam antibiotics including carbapenems. These enzymes are metallo-beta-lactamases having zinc ions in the active site. Beta-lactamases of MBL type are present mainly in aerobic Gram-negative bacilli Stenotrophomonas maltophilia, Pseudomonas spp., Aeromonas spp. and Acinetobacter spp., and they are also present in some bacteria belonging to the family Enterobacteriaceae, e.g. Klebsiella spp., Enterobacter spp., and Morganella spp. $(5,6)$. Recently, there have been identified beta-lactamases of carbapenemases activity, which have been called KPC. These enzymes hydrolyze carbapenems, penicillins, cephalosporins and aztreonam and they are inhibited by clavulanic acid and tazobactam. Beta-lactamases of KPC type have been detected in such strains as Klebsiella spp., Enterobacter spp., Salmonella enterica, Pseudomonas aeruginosa and Serratia spp. (7). Staphylococci have two resistance mechanisms to beta-lactam antibiotics.

\section{WSTĘP}

Oporność na antybiotyki jest poważnym i narastającym problemem zdrowia publicznego. Mikroorganizmy izolowane z zakażeń są coraz częściej oporne na większość, a czasem nawet na wszystkie dostępne leki. Określane są one jako tzw. ,patogeny alarmowe” (12). Problem stanowi zjawisko, w którym drobnoustroje wrażliwe na działanie antybiotyku stają się oporne na skutek procesu horyzontalnej wymiany materiału genetycznego pomiędzy poszczególnymi szczepami danego gatunku, a nawet między gatunkami. Lista czynników alarmowych została określona w Dzienniku Ustaw $\mathrm{Nr}$ 294 - 17195 - Poz. 1741 z dnia 23 grudnia 2011 r. (3). Najbardziej niebezpieczne są metycylinooporne szczepy gronkowca złocistego (methicillin-resistant Staphylococcus aureus, MRSA), enterokoki oporne na wankomycynę (Vancomycin-Resistant Enterococcus, VRE), wielolekooporne niefermentujące szczepy Pseudomonas aeruginosa i Acinetobacter sp., szczepy z rodziny Enterobacteriaceae wytwarzające beta-laktamazy o rozszerzonym spektrum substratowym (ESBL) oraz wytwarzające karbapenemazy: metalo-beta-laktamazy (MBL), beta-laktamazy o aktywności karbapenemaz (Klebsiella pneumoniae carbapenemase, KPC) i OXA-48 (4). Szczególnie trudne do zwalczania są szczepy Gram-ujemnych bakterii wytwarzające ESBL, MBL i cefalosporynazy (AmpC).

W połowie lat 90. ubiegłego wieku zidentyfikowano enzymy hydrolizujące szerokie spektrum antybiotyków beta-laktamowych, w tym karbapenemy. Enzymami tymi są metalo-beta-laktamazy posiadające $\mathrm{w}$ centrum aktywnym jony cynku. Beta-laktamazy MBL występują u Gram-ujemnych pałeczek, głównie tlenowych tj. Stenotrophomonas maltophilia, Pseudomonas spp., Aeromonas spp. i Acinetobacter spp., a także u niektórych bakterii z rodziny Enterobacteriaceae, np. Klebsiella spp., Enterobacter spp., Morganella spp. $(5,6)$. Niedawno zidentyfikowano beta-laktamazy o aktywności karbapenemaz, które nazwano - KPC. Enzymy te hydrolizują karbapenemy, penicyliny, cefalosporyny oraz aztreonam i są hamowane przez kwas klawulanowy oraz tazobaktam. Beta-laktamazy typu KPC wykryto w szczepach m.in. Klebsiella spp., Enterobacter spp., Salmonella enterica, Pseudomonas aeruginosa i Serratia spp. (7). Gronkowce 
One of them is the production of $\beta$-lactamases that causes the resistance to natural penicillins, amino and ureidopenicillins. The second one is the production of a new protein PBP2a, known also as PBP2', with low affinity to $\beta$-lactam antibiotics resulting in resistance to all beta-lactam antibiotics and defined as resistance to methicillin (8).

The aim of this study was the analysis of alert strains occurrence and also their resistance to antibiotics in diagnostic materials, such as sputum and bronchoalveolar lavage (BAL) obtained from patients hospitalized at the Department of Pulmonary Diseases and Tuberculosis, Public Clinical Hospital No 3 in Zabrze, Medical University of Silesia in Katowice, Poland, in the years 2008-2012. The analysis allowed for determining microbial alert species occurring most frequently and their trend of resistance.

\section{MATERIAL AND METHODS}

\section{Study design}

We evaluated the results of bacteriological analysis of sputum and bronchoalveolar lavage taken from patients hospitalized at the Department of Pulmonary Diseases and Tuberculosis, Public Clinical Hospital No 3 in Zabrze, Poland from January 2008 to December 2012. The patients were hospitalized for chronic obstructive pulmonary disease, interstitial lung fibrosis, lung cancer, unspecified obstructive lung disease, Wegener's granulomatosis, pneumonia, bronchiectasis, sarcoidosis, cystic fibrosis, asthma, emphysema, and pulmonary tuberculosis. The analysis included Gram-positive and Gram-negative alert species strains from the period of five years as well as drug resistance profiles of applicable classes of antibiotics used in the treatment of infections.

\section{Microbiological analysis}

The microbiological analysis involved 3810 tests of bronchoalveolar lavage (BAL) and sputum. The list of alert pathogens was specified in the Law Gazette, Annex 1 to the Regulation of the Minister of Health. The analysis does not include the antibiotics of carbapenem groups due to the change of diagnostic recommendations from the Clinical and Laboratory Standards Institute (CLSI) to the European Committee on Antimicrobial Susceptibility Testing (EUCAST) in 2011 which resulted in diversity of the analyzed results. The study was performed at the microbiological laboratory of the Department of Microbiology and Immunology in Zabrze, registered by National Chamber of Laboratory Diagnosticians under the registration number 2397.

The susceptibility of antibiotics was tested by the disk diffusion method (Kirby-Bauer) on Mueller-Hinton Agar plates. The diameters of the growth inhibition zones were interpreted according to EUCAST guidelines (9). For the determination natomiast posiadają dwa mechanizmy oporności na antybiotyki beta-laktamowe. Jednym z nich jest produkcja beta-laktamaz skutkująca opornością na penicyliny naturalne, amino i ureidopenicyliny. Drugim jest produkcja nowego białka PBP2a, zwanego także PBP2' o niskim powinowactwie do antybiotyków beta-laktamowych skutkującą opornością na wszystkie antybiotyki beta-laktamowe obecnie stosowane w leczeniu i określaną mianem oporności na metycylinę (8).

Celem podjętych badań była analiza występowania drobnoustrojów alarmowych, a także ocena ich lekooporności w materiałach diagnostycznych tj. próbkach plwociny i popłuczynach oskrzelowych, uzyskanych od pacjentów hospitalizowanych w Klinice Chorób Płuc i Gruźlicy Samodzielnego Publicznego Szpitala Klinicznego nr 3 w Zabrzu, Śląskiego Uniwersytetu Medycznego w Katowicach w latach 2008-2012. Analiza ta pozwoliła określić gatunki drobnoustrojów alarmowych występujące najczęściej oraz określić ich trend oporności.

\section{MATERIAŁ I METODY}

\section{Projekt badania}

Ocenie poddano wyniki badań bakteriologicznych próbek plwociny i popłuczyn oskrzelowych pobranych od pacjentów hospitalizowanych w Klinice Chorób Płuc i Gruźlicy, Samodzielnego Publicznego Szpitala Klinicznego Nr 3 w Zabrzu od stycznia 2008 do grudnia 2012. Pacjenci byli hospitalizowani z powodu schorzeń układu oddechowego: przewlekłej obturacyjnej choroby płuc, śródmiąższowego włóknienia płuc, nowotworu płuca, nieokreślonej zaporowej choroby płuc, ziarniniaka Wegenera, zapalenia płuc, rozstrzenia oskrzeli, sarkoidozy, mukowiscydozy, astmy, rozedmy płuc i gruźlicy płuc. Analizą zostały objęte gatunki szczepów alarmowych Gram-dodatnich i Gram-ujemnych, występujących w okresie pięciu lat oraz profile lekooporności grup antybiotyków mających zastosowanie w leczeniu zakażeń.

\section{Analiza mikrobiologiczna}

Analiza mikrobiologiczna obejmowała 3810 badań popłuczyn oskrzelowych (BAL) oraz próbek plwociny. Lista drobnoustrojów alarmowych została określona w Dzienniku Ustaw w załączniku Nr 1 do rozporządzenia Ministra Zdrowia. Ze względu na zmianę rekomendacji diagnostycznych w 2011 r., z rekomendacji CLSI (Clinical and Laboratory Standards Institute) na EUCAST (European Committee on Antimicrobial Susceptibility Testing) i wynikających z tego faktu niejednorodności analizowanych wyników, nie uwzględniono w niniejszej analizie antybiotyków z grupy karbapenemów. Badania wykonano w Laboratorium Mikrobiologicznym Katedry i Zakładu Mikrobiologii i Immunologii SUM w Zabrzu, wpisanym na listę Krajowej Izby Diagnostów Laboratoryjnych z nr ewidencyjnym 2397. 
of ESBL production, the Double Disk Synergy Test (DDST) was used $(10,11)$. In this test, synergy was determined between a disk of augmentin $(20 \mu \mathrm{g}$ amoxicillin and $10 \mu \mathrm{g}$ clavulanic acid) and two discs of the third-generation cephalosporin antibiotics ceftazidime $(30 \mu \mathrm{g})$ and cefotaxime $(30 \mu \mathrm{g})$, on the surface of a Mueller Hinton Agar plates inoculated with the tested organisms. Metallo-beta-lactamases production was detected by combined disc diffusion method using imipenem $(10 \mu \mathrm{g})$ and imipenem/ ethylenediaminetetracetate discs. For the detection of KPC double disc diffusion assay, meropenem $(10 \mu \mathrm{g})$ in combination with phenyl boronic acid $(300 \mu \mathrm{g})$ was used. All of the isolates were identified according to TNW Pro6.5 Program.

\section{Statistical analysis}

For data analysis Microsoft Excel 2007 and Statistica version 10.0 (StatSoft) were used. Fisher test was applied and the $p$-values $<0.05$ was considered significant.

\section{RESULTS}

In the period of five years, 144 strains of alert microorganisms have been isolated. In 2008 the percentage of alert pathogens was $3.9 \%$. In the following years the percentage increased and in 2009 it was $11.3 \%$ and in $2010-11.1 \%$. In 2011 the percentage of alert microorganisms was $16.3 \%$, while in 2012 it was $13.6 \%$. The highest value of the alert microorganisms was noted in 2011. The percentage share of alert microorganism was small in 2008; in the sputum it was $4.5 \%$ and in bronchoalveolar lavage $-1.9 \%$. In the subsequent years 2009-2011, the number of alert strains and their percentage increased and in the case of tested sputum it was $11.4 \% ; 11.9 \%$ and $21.9 \%$, respectively, whereas in 2012 it was $16.7 \%$. In bronchoalveolar lavage the percentage of alert microorganisms remained at a similar level in 2009-2012 and amounted to $11 \%, 9.1 \%, 9.3 \%$, and $10 \%$, respectively. In subsequent years significant differences were found between the incidence of tested alarm organisms $(p=0.043)$ dependent on the tested material. The percentage of alert Gram-negative microorganisms was higher and amounted to $2.6 \%$, $9.1 \%, 7.0 \%, 2 \%$, and $9.5 \%$, while the percentage of alert Gram-positive microorganisms was $1.3 \%, 2.2 \%$, $4.0 \%, 1.1 \%$, and $4.1 \%$.

The cultured Gram-positive alarm microorganisms belonged to the species: MRSA, Streptococcus pneumoniae and Streptococcus pyogenes. The most numerous species of alert Gram-negative microorganisms were: Enterobacter cloacae ESBL $(+)$, Klebsiella pneumoniae ESBL $(+)$, Enterobacter
Lekowrażliwość oznaczano metodą dyfuzyjno-krążkową (Kirby-Bauera) na podłożu Mueller-Hintona. Wielkość strefy zahamowania wzrostu bakterii interpretowano zgodnie z zaleceniami EUCAST (9). Do określenia mechanizmu ESBL zastosowano test dwóch krążków, DDST (ang. double-disc synergy test) $(10,11)$. W teście tym określano synergizm pomiędzy krążkiem z augmentinem $(20 \mu \mathrm{g}$ amoksycylina i $10 \mu \mathrm{g}$ kwas klawulanowy) a dwoma krążkami z cefalosporynami trzeciej generacji ceftazydymem $(30 \mu \mathrm{g})$ i cefotaksymem $(30 \mu \mathrm{g})$. Produkcję metalo-beta-laktamaz określano przy użyciu krążków imipenem $(10 \mu \mathrm{g})$ i imipenem/EDTA. W celu detekcji mechanizmu oporności KPC zastosowano krążki z meropenemem (10 $\mu \mathrm{g}) \mathrm{w}$ kombinacji z kwasem fenyloboronowym (300 $\mu \mathrm{g})$. Wszystkie szczepy zostały zidentyfikowane przy użyciu program TNW Pro6.5.

\section{Analiza statystyczna}

W analizie statystycznej wykorzystano arkusz kalkulacyjny Microsoft Excel 2007 oraz program Statistica wersja 10.0 (StatSoft). Zastosowano test Fishera, poziom istotności statystycznej wynosił $\mathrm{p}<0,05$.

\section{WYNIKI}

W okresie pięciu lat wyizolowano 144 szczepy drobnoustrojów alarmowych. W 2008 roku odsetek patogenów alarmowych wynosił 3,9\%. W kolejnych dwóch latach odsetek wzrósł i wynosił w 2009 r. 11,3\%, a w 2010 $11,1 \%$. W 2011r. odsetek drobnoustrojów alarmowych wyniósł 16,3\%, natomiast w 2012 roku 13,6\%. Najwyższa wartość odsetka drobnoustrojów alarmowych przypadła na 2011 rok. Odsetkowy udział drobnoustrojów alarmowych w 2008 roku był niewielki i w próbkach plwociny wynosił 4,5\%, a w popłuczynach oskrzelowych $1,9 \%$. W kolejnych latach 2009-2011 liczba szczepów alarmowych oraz ich odsetek wzrastały i w przypadku badanych próbek plwociny, odsetek wynosił: 11,4\%; 11,9\% i $21,9 \%$, a w 2012 roku - 16,7\%.W popłuczynach oskrzelowych odsetek drobnoustrojów alarmowych w latach 2009-2012 utrzymywał się na podobnym poziomie i wynosił: $11 \% ; 9,1 \% ; 9,3 \% ; 10 \%$. Stwierdzono istotnie częściej występujące w kolejnych latach różnice pomiędzy częstością występowania badanych drobnoustrojów alarmowych $(\mathrm{p}=0,043)$ w zależności od badanego materiału. Odsetek drobnoustrojów alarmowych Gram-ujemnych był większy i wynosił: $2,6 \% ; 9,1 \% ; 7,0 \% ;, 2 \% ; 9,5 \%$. Natomiast odsetek drobnoustrojów alarmowych Gram-dodatnich wynosił: $1,3 \% ; 2,2 \% ; 4,0 \% ; 1,1 \% ; 4,1 \%$.

Wyhodowane drobnoustroje alarmowe Gram-dodatnie należały do gatunku: MRSA, Streptococcus pneumoniae i Streptococcus pyogenes. Najliczniej występującymi gatunkami drobnoustrojów alarmowych Gram-ujemnych były: Enterobacter cloaceae ESBL 
aerogenes ESBL (+), Serratia odorifera ESBL (+), Pseudomonas aeruginosa, Klebsiella oxytoca ESBL $(+)$ and Stenotrophomonas maltophilia. Gram-negative microorganisms showed the highest rate of resistance to penicillins and penicillins with inhibitors and cephalosporins. The rate of resistance to penicillins and penicillin with inhibitors in a five year period was respectively: $100 \%, 90.5 \%, 76.2 \%, 82.5 \%$ and $95.6 \%$. In the following years the rate of resistance to cephalosporin was: $100 \%, 71.4 \%, 90.5 \%, 87.5 \%$ and $100 \%$. Alert Gram-positive microorganisms within five years showed the highest resistance compared to macrolides, which was respectively: $66.7 \%, 100 \%$, $58.3 \%, 66.7 \%$ and $90 \%$. In 2008 and 2010, alert Grampositive microorganism also showed resistance to lincosamides, and it was $66.7 \%$ and $58.3 \%$ respectively. On the other hand, in 2011, the rate of resistance to tetracyclines and macrolides reached the same value, i.e. $66.7 \%$ (Fig. 1 ).
$(+)$, Klebsiella pneumoniae ESBL (+), Enterobacter aerogenes ESBL (+), Serratia odorifera ESBL (+), Pseudomonas aeruginosa, Klebsiella oxytoca ESBL (+) oraz Stenotrophomonas maltophilia. Drobnoustroje Gram-ujemne wykazały najwyższy odsetek oporności w stosunku do penicylin oraz penicylin z inhibitorami oraz cefalosporyn. Odsetek oporności w stosunku do penicylin i penicylin $\mathrm{z}$ inhibitorami w ciągu pięciu lat wyniósł odpowiednio: 100\%, 90,5\%, 76,2\%, $82,5 \%$ oraz $95,6 \%$. Odsetek oporności w stosunku do cefalosporyn wyniósł w kolejnych latach: 100\%, $71,4 \%, 90,5 \%, 87,5 \%$ i $100 \%$. Drobnoustroje alarmowe Gram-dodatnie w okresie pięciu lat wykazały najwyższą oporność w stosunku do makrolidów, odpowiednio: 66,7\%, 100\%, 58,3\%, 66,7\% i 90\%. W 2008 i 2010 drobnoustroje alarmowe Gram-dodatnie wykazały oporność również w stosunku do linkozamidów, odpowiednio: 66,7\% i 58,3\%. Z kolei w 2011 roku odsetek oporności w stosunku do tetracyklin i makrolidów osiągnął taką samą wartość: 66,7\%. (Fig.1).

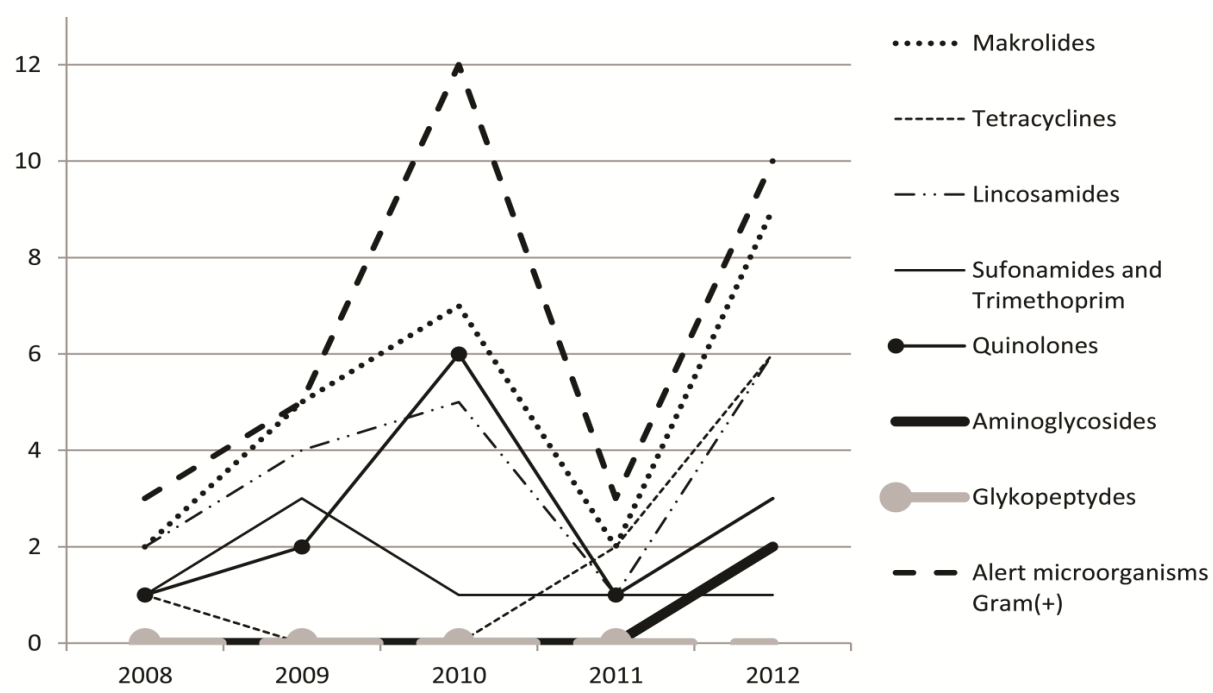

Fig. 1 The number of the Gram (+) alert microorganisms showing resistance to individual classes of antibiotics cultured in sputum and BAL in 2008-2012

Fig. 1 Zestawienie liczby Gram (+) drobnoustrojów alarmowych wykazujących oporność w stosunku do poszczególnych grup antybiotyków wyizolowanych z próbek plwociny i BAL-u w latach 2008-2012

\subsection{The percentage share of alert Gram-positive microorganisms and resistance to antibiotics}

In 2008-2012, alert Gram-positive microorganisms belonging to the following species: MRSA, Streptococcus pneumoniae, Streptococcus pyogenes were cultured in the tested materials. In 2008 and 2009 MRSA constituted $0.9 \%$ of the total number of pathogenic strains. Streptococcus pneumoniae constituted $0.4 \%$ of the total number of pathogenic strains in 2008, and $1.3 \%$ in 2009. In 2010 the percentage share of MRSA in the studied materials increased and amounted to $2.4 \%$, of which $1.7 \%$ strains were cultured from sputum and $0.7 \%$ strains come from bronchoalveolar lavage. The percentage share of Streptococcus pneumoniae

\subsection{Odsetkowy udział poszczególnych gatun-} ków drobnoustrojów alarmowych Gram-dodatnich w latach 2008-2012

W latach 2008-2012 wyizolowano z badanych materiałów drobnoustroje alarmowe Gram-dodatnie, należące do gatunku: MRSA, Streptococcus pneumoniae, Streptococcus pyogenes. W roku 2008 i 2009 MRSA stanowił 0,9\% ogólnej liczby szczepów chorobotwórczych. Streptococcus pneumoniae w 2008 roku stanowił $0,4 \%$, w 2009 - 1,3\% ogólnej liczby szczepów chorobotwórczych. W 2010 roku odsetek MRSA w badanych materiałach zwiększył się i wyniósł 2,4\%, gdzie $1,7 \%$ to szczepy izolowane z próbek plwociny, a $0,7 \%$ to szczepy izolowane z popłuczyn oskrzelowych. Odsetek 
was $0.3 \%$, and that of Streptococcus pyogenes it was $1.3 \%$, of which $1 \%$ strains were cultured in sputum, and $0.3 \%$ in bronchoalveolar lavage. In 2011, the percentage share of MRSA was $0.8 \%$ and that of Streptococcus pyogenes $0.4 \%$. The highest percentage share of MRSA was noted in $2012-4.2 \%$, of which $1.7 \%$ strains were cultured in sputum and $2.5 \%$ strains were cultured in bronchoalveolar lavage.

Macrolides, tetracyclines, lincosamides, quinolones, glycopeptides, aminoglycosides, sulfonamides and trimethoprim are groups of antibiotics referred to determine the susceptibility of Gram $(+)$ microorganisms. Alert microorganisms showed the highest resistance to macrolides and lincosamides $(66.7 \%)$ in 2008 , to macrolides $(100 \%)$ in 2009 , to macrolides $(58.3 \%)$ in 2010 , to macrolides $(66.7 \%)$ in 2011 and macrolides (90\%) in 2012 (Fig. 1).

\subsection{The percentage share of alert Gram-negative microorganisms and resistance to antibiotics}

In 2008, alert Gram-negative microorganisms belonging to Enterobacteriaceae family were found in the tested material. Enterobacter cloacae ESBL $(+)$ was the bacterial strain which constituted the largest percentage share $(0.9 \%)$. In 2009, bacteria from Enterobacteriaceae family as well as non-fermenting bacteria were found among alert microorganisms. Klebsiella pneumoniae ESBL $(+)$ was the species of the highest percentage share (2.1\%) and then in 2010 it was Pseudomonas aeruginosa (1.3\%) and Enterobacter cloacae ESBL $(+)$ (1.3\%), in 2011, Klebsiella pneumoniae ESBL $(+)-6.1 \%$ and in 2012, Klebsiella oxytoca ESBL $(+)-3.8 \%$.

Penicillins, penicillins with inhibitors, cephalosporins, tetracyclines, sulfonamides and trimethoprim, quinolones, aminoglycosides are groups of antibiotics indicated for determining drug sensitivity of Gram-negative microorganisms. The alert microorganisms showed the highest resistance to penicillins, penicillins with inhibitors and cephalosporins (100\%) in 2008, to penicillins and penicillins with inhibitors $(90.5 \%)$ in 2009 , to cephalosporins $(90.5 \%)$ in 2009 , to cephalosporins $(87.5 \%)$ in 2011, and to cephalosporins $(100 \%)$ in 2012 (Fig. 2)

1.3. The number and percentage of Gram-negative and Gram-positive alert microorganisms resistant to various groups of antibiotics cultured in sputum and $B A L$ in 2008-2012

The alert microorganisms showed the highest percentage of resistance to penicillin, penicillin with inhibitors, cephalosporins and tetracyclines (66.7\%) in 2008 , to penicillin and penicillin with inhibitors $(73 \%)$ in 2009 , to cephalosporins $(57.5 \%)$ in 2010 , to
Streptococcus pneumoniae - 0,3\%, a odsetek Streptococcus pyogenes $-1,3 \%$, gdzie $1 \%$ to szczepy izolowane z próbek plwociny, a 0,3\% z popłuczyn oskrzelowych. W 2011 roku odsetek MRSA wynosił 0,8\% a Streptococcus pyogenes - 0,4\%. W 2012 roku zanotowano największy odsetek MRSA - 4,2\%, gdzie 1,7\% to szczepy izolowane z próbek plwociny, a 2,5\% to szczepy izolowane z popłuczyn oskrzelowych.

Makrolidy, tetracykliny, linkozamidy, chinoliny, glikopeptydy, aminoglikozydy oraz sulfonamidy i trimetoprim to grupy antybiotyków wskazane do oznaczania lekowrażliwości drobnoustrojów Gram-dodatnich. Drobnoustroje alarmowe wykazały najwyższą oporność w 2008r. w stosunku do makrolidów i linkozamidów - 66,7\%, w 2009 r. do makrolidów - 100\%, w 2010 r. do makrolidów - 58,3\%, w 2011 r. do makrolidów i tetracyklin - 66,7\%, a w 2012 w stosunku do makrolidów 90\% (Fig. 1).

1.2. Odsetkowy udział poszczególnych gatunków drobnoustrojów alarmowych Gram-ujemnych w latach 2008-2012

W 2008 r. wyizolowano z badanych materiałów drobnoustroje alarmowe Gram-ujemne, należące do rodziny Enterobacteriaceae. Szczepem występującym w najwyższym odsetku był Enterobacter cloaceae ESBL (+) - 0,9\%. W 2009 r. wśród wyhodowanych drobnoustrojów alarmowych znalazły się drobnoustroje z rodziny Enterobacteriaceae oraz z rodziny pałeczek niefermentujących. Gatunkiem występującym w najwyższym odsetku była Klebsiella pneumoniae ESBL (+) - 2,1\%. W 2010 szczep alarmowy występujący w najwyższym odsetku należał do gatunku: Pseudomonas aeruginosa - 1,3\% oraz Enterobacter cloaceae ESBL (+) - 1,3\%. W 2011 r. Klebsiella pneumoniae ESBL (+) - 6,1\%, w 2012 r. Klebsiella oxytoca $\operatorname{ESBL}(+)-3,8 \%$

Penicyliny oraz penicyliny $\mathrm{z}$ inhibitorami, cefalosporyny, tetracykliny, sulfonamidy i trimetoprim, chinolony, aminoglikozydy to grupy antybiotyków wskazane do oznaczania lekowrażliwości drobnoustrojów Gram-ujemnych. Drobnoustroje alarmowe wykazały najwyższą oporność w 2008 r. w stosunku do: penicylin oraz penicylin z inhibitorami i cefalosporyn - 100\%, w 2009 do penicylin oraz penicylin $\mathrm{z}$ inhibitorami 90,5\%, w 2010 do cefalosporyn - 90,5\%, w 2011 do cefalosporyn $-87,5 \%$, w 2012 do cefalosporyn - 100\%, (Fig. 2)

1.3. Liczba oraz odsetek Gram-ujemnych i Gram-dodatnich drobnoustrojów alarmowych wyizolowanych z próbek plwociny i BAL-u w latach 2008-2012, opornych na poszczególne grupy antybiotyków.

Drobnoustroje alarmowe wykazały najwyższy odsetek oporności w 2008 r. w stosunku do: penicylin oraz penicylin z inhibitorami, cefalosporyn i tetracyklin - 66,7\%, w 2009 r. do penicylin oraz penicy- 
cephalosporins (81.4\%) in 2011 and to cephalosporins lin z inhibitorami - 73\%, w 2010 r. do cefalosporyn $(69.6 \%)$ in 2012 (Fig. 3, Table 1).

- 57,5\%, w 2011 r. do cefalosporyn - 81,4\% i w 2012 r. do cefalosporyn $69,6 \%$ (Fig.3, Tabela 1).

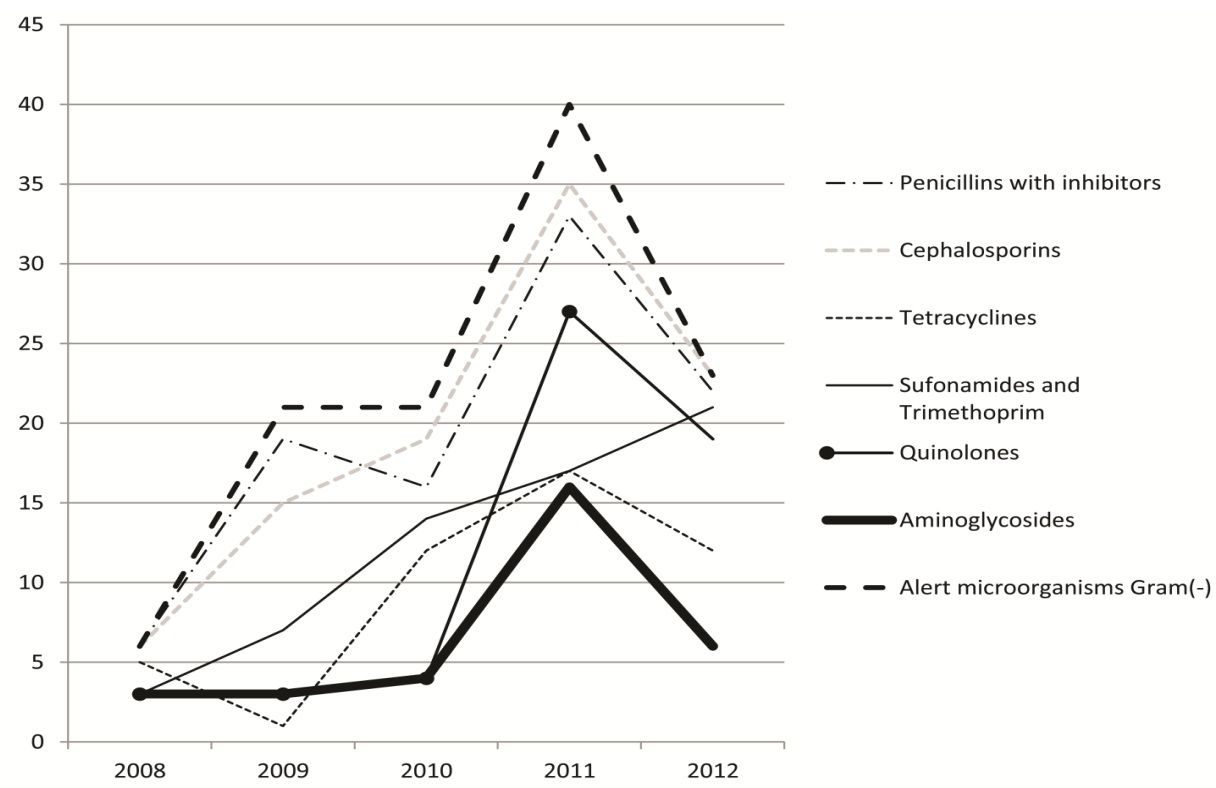

Fig. 2 The number of Gram (-) alert microorganisms showing resistance to individual classes of antibiotics cultured in sputum and BAL in 2008-2012

Fig. 2 Zestawienie liczby Gram-ujemnych drobnoustrojów alarmowych wykazujących oporność w stosunku do poszczególnych grup antybiotyków wyizolowanych z próbek plwociny i BAL-u w latach 2008-2012

Tabela I. Gram-positive and Gram-negative alert pathogens resistance to antibiotics isolated from BAL and sputum from 2008 to 2012

Table I. Gram-positive and Gram-negative alert pathogens resistance to antibiotics isolated from BAL and sputum from 2008 to 2012

\begin{tabular}{|c|c|c|c|c|c|c|c|c|c|c|}
\hline \multirow{3}{*}{ Antibiotics } & \multicolumn{10}{|c|}{ Year } \\
\hline & \multicolumn{2}{|c|}{2008} & \multicolumn{2}{|c|}{2009} & \multicolumn{2}{|c|}{2010} & \multicolumn{2}{|c|}{2011} & \multicolumn{2}{|c|}{2012} \\
\hline & $\begin{array}{c}G(+) \\
(3)\end{array}$ & $\begin{array}{l}\text { G(-) } \\
(6)\end{array}$ & $\begin{array}{c}G(+) \\
(5)\end{array}$ & $\begin{array}{l}\text { G(-) } \\
(21)\end{array}$ & $\begin{array}{l}G(+) \\
(12)\end{array}$ & $\begin{array}{l}\text { G(-) } \\
(21)\end{array}$ & $\begin{array}{c}G(+) \\
(3)\end{array}$ & $\begin{array}{l}\text { G(-) } \\
(40)\end{array}$ & $\begin{array}{l}G(+) \\
(10)\end{array}$ & $\begin{array}{l}\text { G(-) } \\
(23)\end{array}$ \\
\hline Macrolides & $\begin{array}{c}2^{\mathrm{a}} \\
(66.7)^{\mathrm{b}}\end{array}$ & - & $\begin{array}{c}5 \\
(\mathbf{1 0 0})\end{array}$ & - & $\begin{array}{c}7 \\
\mathbf{( 5 8 . 3 )} \\
\end{array}$ & - & $\begin{array}{c}2 \\
(66.7) \\
\end{array}$ & - & $\begin{array}{c}9 \\
(90.0)\end{array}$ & - \\
\hline Tetracyclines & $\begin{array}{c}1 \\
(33.3)\end{array}$ & $\begin{array}{c}5 \\
(83.3)\end{array}$ & - & $\begin{array}{c}1 \\
(4.8)\end{array}$ & - & $\begin{array}{c}12 \\
(\mathbf{5 7 . 1})\end{array}$ & $\begin{array}{c}2 \\
(66.7)\end{array}$ & $\begin{array}{c}17 \\
(\mathbf{4 2 . 5 )}\end{array}$ & $\begin{array}{c}6 \\
(\mathbf{6 0 . 0})\end{array}$ & $\begin{array}{c}12 \\
(\mathbf{5 2 . 2})\end{array}$ \\
\hline Linkosamides & $\begin{array}{c}2 \\
(66.7)\end{array}$ & - & $\begin{array}{c}4 \\
(80)\end{array}$ & - & $\begin{array}{c}5 \\
(41.7)\end{array}$ & - & $\begin{array}{c}1 \\
(33.3)\end{array}$ & - & $\begin{array}{c}6 \\
(\mathbf{6 0 . 0})\end{array}$ & - \\
\hline $\begin{array}{l}\text { Sulphonamides } \\
\text { and trimethoprim }\end{array}$ & $\begin{array}{c}1 \\
(33.3)\end{array}$ & $\begin{array}{c}3 \\
(\mathbf{5 0 . 0})\end{array}$ & $\begin{array}{c}3 \\
(60)\end{array}$ & $\begin{array}{c}7 \\
(33.3)\end{array}$ & $\begin{array}{c}1 \\
(8.3)\end{array}$ & $\begin{array}{c}14 \\
(66.7)\end{array}$ & $\begin{array}{c}1 \\
(33.3)\end{array}$ & $\begin{array}{c}17 \\
(\mathbf{4 2 . 5 )}\end{array}$ & $\begin{array}{c}1 \\
(\mathbf{1 0 . 0})\end{array}$ & $\begin{array}{c}21 \\
(\mathbf{9 1 . 3})\end{array}$ \\
\hline Chinolones & $\begin{array}{c}1 \\
(33.3)\end{array}$ & $\begin{array}{c}3 \\
(\mathbf{5 0 . 0})\end{array}$ & $\begin{array}{c}2 \\
(40)\end{array}$ & $\begin{array}{c}3 \\
(14.3)\end{array}$ & $\begin{array}{c}6 \\
(\mathbf{5 0 . 0 )}\end{array}$ & $\begin{array}{c}4 \\
(19.0)\end{array}$ & $\begin{array}{c}1 \\
(33.3)\end{array}$ & $\begin{array}{c}27 \\
(67.5)\end{array}$ & $\begin{array}{c}3 \\
(30.0)\end{array}$ & $\begin{array}{c}19 \\
(\mathbf{8 2 . 6})\end{array}$ \\
\hline Aminoglycosides & - & $\begin{array}{c}3 \\
(\mathbf{5 0 . 0})\end{array}$ & - & $\begin{array}{c}3 \\
(14.3)\end{array}$ & - & $\begin{array}{c}4 \\
(\mathbf{1 9 . 0})\end{array}$ & - & $\begin{array}{c}16 \\
(40)\end{array}$ & $\begin{array}{c}2 \\
(\mathbf{2 0 . 0})\end{array}$ & $\begin{array}{c}6 \\
(26.1)\end{array}$ \\
\hline $\begin{array}{l}\text { Penicillins/ penicillins } \\
\text { with inhibitors }\end{array}$ & - & $\begin{array}{c}6 \\
(\mathbf{1 0 0})\end{array}$ & - & $\begin{array}{c}19 \\
(\mathbf{9 0 . 5 )}\end{array}$ & - & $\begin{array}{c}16 \\
(\mathbf{7 6 . 2})\end{array}$ & - & $\begin{array}{c}33 \\
(\mathbf{8 2 . 5})\end{array}$ & - & $\begin{array}{c}22 \\
(\mathbf{9 5 . 7})\end{array}$ \\
\hline Cephalosporins & - & $\begin{array}{c}6 \\
(\mathbf{1 0 0 )}\end{array}$ & - & $\begin{array}{c}15 \\
(\mathbf{7 1 . 4 )}\end{array}$ & - & $\begin{array}{c}19 \\
(\mathbf{9 0 . 5 )}\end{array}$ & - & $\begin{array}{c}35 \\
(\mathbf{8 7 . 5})\end{array}$ & - & $\begin{array}{c}23 \\
(\mathbf{1 0 0})\end{array}$ \\
\hline
\end{tabular}

aalues in parentheses indicate the number of alert pathogens found in each year.

${ }^{b}$ Values in parentheses indicate the percentage of alert pathogens found in each year.

The bolded data indicate the total number and percentage of that group 
There were statistically significant differences between the incidence of both pathogenic and alert microorganisms $(p=0.043)$ in the following years depending on the material tested.

\section{DISCUSSION}

Infections caused by alert pathogens have become one of the most important problems of modern medicine. The alert microorganisms constitute a considerable part of pathogenic flora isolated from sputum and bronchoalveolar lavage in patients hospitalized for lung diseases at the Department of Pulmonary Diseases and Tuberculosis. Based on the obtained results it is difficult to draw definite conclusions regarding the trend of changes of the assessed indicator in subsequent years. One can only conclude that in comparison to the first analyzed year, in subsequent years this indicator has increased significantly and fluctuates around an average value of about $13 \%$. The percentage of Gram-negative alert microorganisms was higher than that of Gram-positive alert microorganisms. Grampositive bacteria cause exacerbation of many lower respiratory tract diseases. Infections are most common in long-term hospitalized patients, patients with prolonged mechanical ventilation, patients undergoing broad-spectrum antibiotic treatment, patients after invasive diagnostic procedures, patients with a serious underlying disease, such as, e.g. chronic obstructive pulmonary disease (COPD), cancer, cystic fibrosis, as well as patients with immunosuppression or neutropenia (12-15).

Until 2012, there were no publications showing the incidence of alert microorganisms in inpatient medical facilities in individual provinces of Poland. Some information can be found only on the websites of provincial sanitary and epidemiological stations. In Lesser Poland Province in 2012, in comparison to the years 2011 and 2010, there was increased percentage share of Enterobacteriaceae ESBL $(+)$ family (Klebsiella sp., Escherichia coli, Enterobacter sp.), $30 \%, 27 \%$ and $27 \%$, respectively. In the same years, a similar upward trend remained in Greater Poland Province with regard to the percentage share of Enterobacteriaceae ESBL+ $(24.6 \%, 16.8 \%$ and $17.3 \%$, respectively). In 2012, as compared to 2011 and 2010, in Lesser Poland the number of Acinetobacter baumannii infections decreased slightly $(12 \%, 14 \%$ and $14 \%$, respectively). In 2012, the percentage of patients with MRSA infections was similar in both provinces (about 10\%) (16).

In 2012, in West Pomeranian Province the following alert microorganism dominated in medical wards, surgical wards and intensive care units for adult patients: Klebsiella spp. ESBL $(+)-(16.72 \%)$,
Stwierdzono istotnie częściej występujące w kolejnych latach różnice pomiędzy częstością występowania badanych drobnoustrojów zarówno chorobotwórczych, jak i alarmowych $(\mathrm{p}=0,043)$ w zależności od badanego materiału.

\section{DYSKUSJA}

Zakażenia powodowane przez patogeny alarmowe stały się jednym z najważniejszych problemów współczesnej medycyny. Drobnoustroje alarmowe stanowią znaczną część flory chorobotwórczej izolowanej z próbek plwociny i popłuczyn oskrzelowych pochodzących od pacjentów hospitalizowanych na oddziale chorób płuc. Na podstawie uzyskanych wyników trudno wyciągnąć jednoznaczne wnioski odnośnie trendu zmian ocenianego wskaźnika w kolejnych latach. Można jedynie stwierdzić, że w stosunku do pierwszego analizowanego roku w kolejnych latach wskaźnik ten wzrósł istotnie i oscyluje wokół średniej wartości ok. 13\%. Odsetek drobnoustrojów alarmowych Gram-ujemnych był większy od drobnoustrojów alarmowych Gram-dodatnich. Drobnoustroje Gram-ujemne są przyczyną zaostrzeń wielu chorób dolnych dróg oddechowych. Zakażeniom najczęściej ulegają pacjenci długotrwale hospitalizowani, pacjenci z przedłużającą się wentylacją mechaniczną, poddawani antybiotykoterapii o szerokim spektrum, po inwazyjnych zabiegach diagnostycznych, z poważną chorobą podstawową np. z POChP, z chorobą nowotworową, z mukowiscydozą, w stanach immunosupresji, w neutropenii (12-15).

Do roku 2012 nie istniały publikacje, które przedstawiałyby częstość występowania drobnoustrojów alarmowych w placówkach lecznictwa zamkniętego w poszczególnych województwach Polski. Pojedyncze informacje w tym zakresie można odnaleźć jedynie na stronach internetowych wojewódzkich stacji sanitarno-epidemiologicznych. W Małopolsce w roku 2012 w porównaniu z latami 2011 i 2010 stwierdzono zwiększenie udziału procentowego pałeczek z rodziny Enterobacteriaceae ESBL (+) (Klebsiella sp., Escherichia coli, Enterobacter sp.) odpowiednio: 30\%, 27\% i $27 \%$. Podobna tendencja wzrostowa utrzymywała się w tych latach w województwie wielkopolskim w zakresie udziału procentowego pałeczek Enterobacteriaceae ESBL (+) odpowiednio 24,6\%, 16,8\% i 17,3\%. W 2012 r., w porównaniu z latami 2011 i 2010, w Małopolsce liczba zakażeń Acinetobacter baumannii nieznacznie spadła (odpowiednio 12\%, 14\% i 14\%). Odsetek pacjentów z zakażeniem wywołanym szczepem MRSA w 2012 r. był podobny w obu województwach (około 10\%) (16).

W województwie zachodniopomorskim w 2012 na oddziałach niezabiegowych dla dorosłych, zabie- 
Escherichia coli ESBL $(+)-(9.86 \%)$, Enterobacter spp. ESBL $(+)-(4.57 \%)$, MRSA $-(10.83 \%)$, Acinetobacter- $-(6.71 \%)$.

The greatest number of Pseudomonas aeruginosa strains was found in the hospital wards mentioned above and also in burns unit (8.65\%) (17). From 2012 reports on the sources of hospital-acquired infections have been collected under the new regulation of the Minister of Health of 23 December 2011 regarding the list of alert factors, hospital infections registration and reports on the current epidemiological situation of hospital (Law Gazette Nr 294, item. 1741). The most common alert factors which caused outbreaks of epidemic foci in Polish hospitals in the years 2011 and 2012 are: Acinetobacter baumannii 7.7\% and 9\%, Klebsiella pneumoniae ESBL $(+) 5.6 \%$ and $4.7 \%$, Klebsiella pneumoniae KPC $1.5 \%$ and $1.3 \%$, MRSA $6.2 \%$ and $3.7 \%$, Pseudomonas aeruginosa $4.4 \%$ and $1 \%$, Enterobacter cloacae ESBL (+) $1.8 \%$ and $0.7 \%$ (18).

The results of our study are similar to the results obtained by P. Paluchowska at al. who determine the prevalence and susceptibility of alert strains from Enterobacteriaceae family producing ESBL derived from clinical specimens taken from patients hospitalized in different wards of the Rydygier Specialist Hospital in Cracow from October 2008 to February 2010 (19). The total of 134 strains were analyzed, among which there were 96 isolates of Klebsiella pneumoniae (72\%) and 38 isolates of Escherichia coli (28\%). The results obtained by our research also prove that in 2009 Klebsiella pneumoniae ESBL (+) was isolated in the highest percentage of bronchoalveolar lavage and sputum. P. Paluchowska et al., showed that among of all the tested strains, the majority of samples came from the respiratory tract, urine, swabs from wounds and blood (24\%, 24\%, 21\% and 18\%, respectively). The isolates showed the highest sensitivity to amikacin (92\%) and piperacillin with tazobactam (76\%).

In another paper Paluchowska conducted an assessment of the prevalence and susceptibility of nonfermenting bacilli isolated from patients hospitalized in different wards of the Rydygier Specialist Hospital in Cracow from October 2008 to February 2010 (20). $105(70 \%)$ isolates of multidrug-resistant strains Acinetobacter baumannii and $46(30 \%)$ multiresistant strains Pseudomonas aeruginosa, which were the most common species of alert pathogens, were examined. Clinical material from the upper respiratory tract, wounds and blood was the main source of multidrugresistant strains. Acinetobacter baumannii strains were characterized by resistance to most antibiotics used. $100 \%$ strains were found to be piperacillin-resistant, 98\% ticacycline-resistant, $97 \%$ starins were resistant to ticarcillin with clavulanate and $92 \%$ were resistant gowych chirurgicznych dla dorosłych oraz oddziałach intensywnej terapii dorosłych dominowały następujące czynniki alarmowe: Klebsiella spp. ESBL $(+)-$ (16.72\%), Escherichia coli ESBL $(+)-(9.86 \%)$, Enterobacter spp. ESBL $(+)-(4.57 \%)$, MRSA - $(10.83 \%)$, Acinetobacter-(6.71\%). Największą liczbę szczepów Pseudomonas aeruginosa stwierdzono w w/w oddziałach oraz w oddziale oparzeniowym $(8,65 \%)$ (17). Od 2012 roku raporty o ogniskach zakażeń szpitalnych są gromadzone i raportowane w oparciu o nowe rozporządzenie Ministra Zdrowia z dnia 23 grudnia 2011r. $\mathrm{w}$ sprawie listy czynników alarmowych, rejestrów zakażeń szpitalnych oraz raportów o bieżącej sytuacji epidemiologicznej szpitala (Dz. U. Nr 294, poz. 1741). Najczęstsze czynniki alarmowe, które wywoływały ogniska epidemiczne w polskich szpitalach w latach 2011 i 2012 to: Acinetobacter baumannii 7,7\% i 9\%, Klebsiella pneumoniae ESBL (+) 5,6\% i 4,7\%, Klebsiella pneumoniae KPC 1,5\% i 1,3\%, MRSA $6,2 \%$ i 3,7\%, Pseudomonas aeruginosa 4,4\% i 1\%, Enterobacter cloacae ESBL (+) 1,8\% i 0,7\% (18).

Wyniki naszych badań podobne są do wyników uzyskanych przez P. Paluchowska i wsp., którzy analizowali występowanie i określali lekowrażliwość szczepów alarmowych z rodziny Enterobacteriaceae wytwarzających ESBL, pochodzących z materiałów klinicznych pobranych od pacjentów hospitalizowanych w różnych oddziałach Szpitala Specjalistycznego im. L. Rydygiera w Krakowie w okresie od października 2008 do lutego 2010 (19). Analizie poddano 134 szczepy. Wśród nich były: Klebsiella pneumoniae - 96 izolatów (72\%) i Escherichia coli - 38 izolatów (28\%). Wyniki naszych badań również dowodzą, iż w roku 2009 w najwyższym odsetku z popłuczyn oskrzelowych oraz próbek plwociny izolowana była Klebsiella pneumoniae ESBL (+). P. Paluchowska i wsp., wykazali, że spośród wszystkich badanych szczepów większość otrzymano z próbek dróg oddechowych, moczu, wymazów z ran i krwi (odpowiednio $24 \%, 24 \%, 21 \%$ i $18 \%)$. Izolaty wykazały najwyższą wrażliwość na amikacynę (92\%) i piperacylinę z tazobaktamem (76\%).

W kolejnej pracy Paluchowska P. przeprowadziła ocenę częstości występowania oraz lekowrażliwości pałeczek niefermentujących izolowanych od chorych hospitalizowanych w różnych oddziałach Szpitala Specjalistycznego im. L. Rydygiera w Krakowie w okresie od października 2008 do lutego 2010 (20). Przebadano 105 (70\%) izolatów wieloopornych szczepów Acinetobacter baumannii oraz 46 (30\%) wieloopornych szczepów Pseudomonas aeruginosa, które były najczęściej występującymi gatunkami patogenów alarmowych. Głównym źródłem wieloopornych szczepów był materiał kliniczny pochodzący z górnych dróg oddechowych, z ran i krwi. Szczepy Acine- 
to piperacillin with tazobactam. Our study also proved that in 2009 strains of Gram-negative bacteria showed the highest resistance to beta-lactam antibiotics. Paluchowska also noted a high percentage of isolates insensitive to ceftazidime (96\%) and cefepime (99\%).

With regard to aminoglycosides, the percentage of resistant Acinetobacter baumannii strains was $95 \%$ for gentamicin, $36 \%$ for amikacin and $18 \%$ for tobramycin, respectively. There were no strains resistant to fluoroquinolones represented by ciprofloxacin and pefloxacin. The production of metal ß-lactamase MBL using the phenotypic (E-test MBL) method was found among 24 (22.9\%) Acinetobacter baumannii isolates. The highest resistance among strains of Pseudomonas aeruginosa was shown in relation to the ticarcillin (98\%), ticarcillin with clavulanate $(95 \%)$ and ceftazidime (93\%). Resistance to meropenem in $88 \%$ and imipenem in $41 \%$, as well as high resistance to aminoglycosides in the range of $91 \%$ to amikacin of $98 \%$ for gentamicin was found. However, no resistance to fluoroquinolones was detected. Seven strains $(15.2 \%)$ out of 46 tested by E-test method have shown the production of metallo- $\beta$-lactamase (MBL). The production of ESBL was more frequent among Klebsiella pneumoniae isolates.

A. Behroozi et al. noted the most common occurrence of ESBL mechanism in Escherichia coli (from $45.2 \%$ to $67.2 \%$ of isolates) and in Klebsiella pneumoniae (from $44.2 \%$ to $52 \%$ of isolates), which correlates with the above cited Paluchowska's study results and the results obtained by our team (21). Ceftriaxone/tazobactam and piperacillin/tazobactam have shown efficacy against Klebsiella pneumoniae and Escherichia coli producing ESBL mechanism. In turn, amikacin showed efficacy against Escherichia coli $\operatorname{ESBL}(+)$. In works of other authors the efficacy of combination of ceftriaxone with tazobactam has been demonstrated in animal models against several species of bacilli from Enterobacteriaceae family, however there is no information about this kind of antibiotic combination in relation to non-fermenting bacteria (2224). Research of A. Fatima et al. focused on defining the pattern of drug resistance of Pseudomonas aeruginosa, cultured from sputum, which was the cause of lower respiratory tract infections among patients admitted to various hospitals in 2010-2011 (25). Pseudomonas aeruginosa was isolated from $24 \%$ of sputum. Our research has shown that this alarm microorganism was most often isolated in 2010. Researchers showed that the resistance of this bacterium to amikacin was $35 \%$, to piperacillin with tazobactam $42 \%$ and to cefepime $40 \%$. Imipenem turned out to be the most effective antibiotic $(76 \%)$. The resistance of Haemophilus influenzae to penicillins may be subject to change depending on the region. The prevalence of BLNAR tobacter baumannii charakteryzowały się opornością wobec większości stosowanych antybiotyków. Wykazano $100 \%$ szczepów opornych na piperacylinę, $98 \%$ na tikarcylinę, $97 \%$ na tikarcylinę z kwasem klawulanowym oraz $92 \%$ na piperacylinę z tazobaktamem. Wyniki naszych badań również pokazują, iż w roku 2009 szczepy bakterii Gram-ujemnych wykazywały najwyższą oporność w stosunku do antybiotyków beta-laktamowych. Paluchowska P. odnotowała również wysoki procent izolatów o braku wrażliwości na ceftazydym (96\%) oraz cefepim (99\%). W odniesieniu do aminoglikozydów, odsetek opornych szczepów Acinetobacter baumannii wyniósł odpowiednio 95\% dla gentamycyny, $36 \%$ dla amikacyny oraz $18 \%$ dla tobramycyny. Nie stwierdzono szczepów opornych na fluorochinolony reprezentowane przez ciprofloksacynę oraz pefloksacynę. Wytwarzanie metalo-beta-laktamazy MBL, przy użyciu metody fenotypowej (Etest MBL) stwierdzono u 24 (22,9\%) izolatów Acinetobacter baumannii. Największą oporność wśród szczepów Pseudomonas aeruginosa wykazano w odniesieniu do tikarcyliny (98\%), tikarcyliny z kwasem klawulanowym (95\%) oraz ceftazydymu (93\%). Stwierdzono również oporność na meropenem w $88 \%$ i imipenem w 41\%. Odnotowano również wysoką oporność na aminoglikozydy w zakresie od $91 \%$ dla amikacyny do $98 \%$ dla gentamycyny. Nie stwierdzono oporności na fluorochinolony. Siedem szczepów (2\%) spośród 46 badanych w metodzie Etest, wykazało wytwarzanie metalo-beta-laktamazy MBL. Produkcja ESBL występowała częściej u izolatów Klebsiella pneumoniae.

Behroozi A. i wsp. odnotowali najczęstsze występowanie mechanizmu ESBL u Escherichia coli (od $45,2 \%$ do $67,2 \%$ izolatów) i u Klebsiella pneumoniae (od 44,2\% do 52\% izolatów), co koreluje z wyżej przytoczonymi wynikami badań Paluchowskiej $P$. oraz wynikami uzyskanymi przez nasz zespół (21). Ceftriakson/tazobaktam i piperacylina/tazobaktam wykazały skuteczność w stosunku do Klebsiella pneumoniae i Escherichia coli wytwarzające mechanizm ESBL. Amikacyna z kolei wykazała skuteczność na Escherichia coli z mechanizmem oporności ESBL. W pracach innych autorów skuteczność połączenia ceftriaksonu z tazobaktamem została dowiedziona na modelach zwierzęcych w stosunku do kilku gatunków pałeczek z rodziny Enterobacteriaceae, natomiast nie ma pozytywnych informacji działania tego połączenia antybiotyków w stosunku do pałeczek niefermentujących (22-24).

Badania Fatima A. i wsp. skupiły się nad określeniem wzoru lekooporności Pseudomonas aeruginosa, hodowanych z próbek plwociny, który powodował zakażenia dolnych dróg oddechowych u pacjentów przyjmowanych do różnych szpitali w latach 20102011 (25). Pseudomonas aeruginosa wyizolowano 
strains has increased significantly in some countries, such as Japan, Spain and France. A particularly rapid growth was observed in Japan, where it amounted to $5.8 \%$ in 2000 , and $34.5 \%$ in 2004 . The lowest percentage of strains was recorded in Germany 3\%, while in Korea it was $65 \%$ (26).

Our work has shown that over the period of 20082012 an increased percentage of Gram-negative alert pathogens producing ESBL and KPC was observed in Public Clinical Hospital No 3 in Zabrze (Poland). MRSA, Steptococcus pneumoniae and Streptococcus pyogenes have been found to be the most often occurring among Gram-positive alert microorganisms. The percentage of alarm pathogens increased from $2008(3.9 \%)$ to $2011(16.3 \%)$. In 2012, as compared to the last year, a slight decrease of $13.6 \%$ was observed. Gram-negative and Gram-positive pathogens were more frequently isolated. Gram positive alert microorganisms within five years showed the highest resistance to macrolides and lincosamides. Gram negative alert pathogens showed the highest percentage of resistance to penicillins, penicillins with inhibitors and cephalosporins. In the analyzed material, only one case of a mechanism characterized by the presence of metalobetalactamase MBL among Pseudomonas aeruginosa was noted. There was no occurrence of Staphylococcus aureus VISA, VRSA, Enterococcus VRE, Klebsiella pneumoniae KPC (+) nor OXA-48 strains.

\section{Funding}

No funding sources.

\section{Competing interests}

None declared.

\section{Ethical approval}

Not required.

\section{REFERENCES}

1. Frieri M, Kumar K, Boutin A. Antibiotic resistance. J Infect Public Health 2017; 10(4): 369-378.

2. Jaworski R, Haponiuk I, Steffens M, Arlukowicz E, Irga-Jaworska N, Chojnicki M, Kwasniak E, Zielinski J. Colonization of multidrug resistant pathogens in a hybrid pediatric cardiac surgery center. Arch Med Sci 2016; 12(3): 639-44.

3. Czynniki alarmowe oraz analiza sytuacji epidemiologicznej zakażeń szpitalnych w woj. zachodniopomorskim za 2012r. BIP http://wsse.szczecin. pl (accessed 15.02.2016)

4. Fujitani S, Sun HY, Yu V, Weingarten J. Pneumonia due to Pseudomonas aeruginosa Part I: Epidemiology, clinical diagnosis and source. Chest 2011; 139(4): 909-919. z 24\%. Nasze badania wykazały, iż ten drobnoustrój alarmowy najczęściej izolowany był w roku 2010. Badacze wykazali, że oporność Pseudomonas aeruginosa w stosunku do amikacyny wynosiła $35 \%$, w stosunku do piperacyliny $\mathrm{z}$ tazobaktamem $42 \%$, a do cefepimu $40 \%$. Najbardziej skutecznym antybiotykiem okazał się imipenem - 76\%. Oporność Haemophilus influenzae w stosunku do ampicyliny może ulegać zmianom w zależności od regionu. Częstość występowania szczepów BLNAR zwiększyła się znacznie w niektórych krajach, w tym w Japonii, Hiszpanii i Francji. Szczególnie szybki wzrost nastąpił w Japonii, gdzie w 2000 r. wynosił 5,8\%, a w 2004r. 34,5\%. Najniższy odsetek szczepów zanotowano w Niemczech - 3\% natomiast w Korei - 65\% (26).

Wyniki naszych badań pokazują, że w latach 20082012 w Szpitalu Klinicznym nr 3 w Zabrzu nastapił wzrost odsetka Gram-ujemnych patogenów alarmowych produkujących mechanizmy ESBL i KPC. Stwierdzono, że najczęściej występującymi Gram-dodatnimi mikroorganizmami alarmowymi były MRSA, Steptococcus pneumoniae i Streptococcus pyogenes. Odsetek patogenów alarmowych wzrastał od roku $2008(3,9 \%)$ do roku 2011 (16,3\%). W 2012 roku w porównaniu z rokiem ubiegłym zaobserwowano nieznaczny spadek wynoszący 13,6 \%. Częściej izolowano patogeny alarmowe Gram-ujemne niż Gram-dodatnie. W ciągu pięciu lat mikroorganizmy Gram-dodanie wykazały najwyższą odporność w stosunku do makrolidów i linkozamidów. Z kolei bakterie Gram-ujemne w ciągu pięciu analizowanych lat wykazały największą oporność w stosunku do penicylin, penicylin $\mathrm{z}$ inhibitorami i cefalosporyn. W analizowanym materiale zidentyfkowano tylko jeden przypadek mechanizmu MBL, który wykryto u Pseudomonas aeruginosa. Nie wykryto szczepów Staphylococcus aureus VISA, VRSA, Enterococcus VRE, Klebsiella pneumoniae KPC (+) ani OXA-48.

5. Georgopoulos A, Buxbaum A, Graninger W. Efficacy of B-lactam and inhibitor combinations in a diffusion chamber model in rabbits. J Antimicrob Chemother 1999; 43(4): 497-501.

6. Hoban D, Felmingham D. The PROTEKT surveillance study: antimicrobial susceptibility of Haemophilus influenzae and Moraxella catarrhalis from community-acquired respiratory tract infections. J Antimicrob Chemother 2002; 50: 49-59.

7. Hasegawa KN, Chiba R, Kobayashi MS, Iwata S, Sunakawa K, Ubukata K. Rapidly increasing prevalence of $\beta$-lactamase-nonproducing, ampicillin-resistant Haemophilus influenzae type $b$ in patients with meningitis. Antimicrob Agents Chemother 2004; 48(5): 2-14. 
8. Kristof K, Szabo D, Marsh JW. et al. Extended-spectrum beta-lactamase-producing Klebsiella spp. Ina neonatal intensive care unit: risk factors for the infection and the dynamics of the molecular epidemiology. Eur J Clin Microbiol Infect Dis 2007; 26(8): 563-570.

9. The European Committee on Antimicrobial Susceptibility Testing. Breakpoint tables for interpretation of MIC and zone diameters. Version 7.1. 2017, http://www.eucast.org.

10. The European Committee on Antimicrobial Susceptibility Testing. EUCAST disk diffusion method for antimicrobial susceptibility testing. Version 6.0. 2017, http://www.eucast.org.

11. Polsfuss S, Bloemberg GV, Giger J, Meyer V, Hombach M. Comparison of European Committee on Antimicrobial Susceptibility Testing (EUCAST) and CLSI screening parameters for the detection of extended-spectrum $\beta$-lactamase production in clinical Enterobacteriaceae isolates. J Antimicrob Chemother 2012; 67(1): 159-66.

12. Lewis JS, Herrera M, Wickes B, Patterson JE, Jorgensen JH. First report of the emergence of CTX-M-type extended-spectrum beta-lactamases (ESBLs) as the predominant ESBL isolated in a U.S. health care system. Antimicrob Agents Chemother 2007; 51(11): 40-4021.

13. Manchanda V, Sanchaita S, Singh NP. Multidrug resistant Acinetobacter. J Glob Infect Dis 2010; 2(3): 291-304.

14. Rajpurohit HV, Kumar BM, Sharadamma, KC, Radhakrishna PM. In-vitro activity of ceftriaxone in combination with sulbactam and tazobactam against Escherichia coli. Int J Pharm Bio Sci 2011; 1: $545-550$

15. Safdar A, Rolston KV. Stenotrophomonas maltophilia: changing spectrum of a serious bacterial pathogen in patients with cancer. Clin Infect Dis 2007; 45: 1602-1609.

16. Seweryn M, Bandoła K, Bała MM. Drobnoustroje alarmowe wykryte u pacjentów hospitalizowanych $\mathrm{w}$ szpitalach województwa małopolskiego $\mathrm{w}$ latach 2010-2012. Przegl Epidemiol 2014; 68(3): $549-553$

17. Souli M, Kontopidou FV, Papadomichelakis E. Clinical experience of serious infections caused by Enterobacteriaceae producing VIM-1 metallo-beta-lactamase in a Greek University Hospital. Clin Infect Dis 2008; 46: 847-854

18. Stan sanitarny kraju 2014 http://www.gis.gov.pl (accessed 05.01.2016)
19. Paluchowska P, Skałkowska M, Szelak A, Budak A. Występowanie patogenów alarmowych w środowisku szpitalnym. Część I. Pałeczki z rodziny Enterobacteriaceae wytwarzające $\beta$ - laktamazy ESBL. Med Dośw Mikrobiol 2012; 64: 35-43.

20. Paluchowska P, Skałkowska M, Szelak A, Budak A. Występowanie patogenów alarmowych w środowisku szpitalnym. Część II. Wielolekooporne niefermentujące pałeczki. Med Dośw Mikrobiol 2012; 64: 45-53.

21. Behroozi A, Rahbar M, Vand YJ. Frequency of extended- spectrum beta-lactamase (ESBLs) producing Escherichia coli and Klebsiella pneumoniae isolated from urine in an Iranian 1000-bed tertiary care hospital. Afr J Microbiol Res 2010; 4: 881-884.

22. Walsh TR. The emergence and implications of metallobeta - lactamases in Gram-negative bacteria. Clin Microbiol Infect 2005; 11: 2-9.

23. Vatopoulos A. High rates of metallo-beta-lactamase-producing Klebsiella pneumoniae in Greece-a review of the current evidence. Euro Surveill 2008; 13: 1-6.

24. Wanke M. Aktualności Narodowego Programu Ochrony Antybiotyków, 2011, 3:1-5.

25. Fatima A, Naqvi SB, Khaliq SA, Perveen S, Jabeen S. Antimicrobial susceptibility pattern of clinical isolates of Pseudomonas aeruginosa isolated from patients of lower respiratory tract infections. SpringerPlus 2012; 1: 1-4.

26. Zielinska-Borkowska U, Złotorowicz M. Zakażenie szczepami wieloopornymi u chorych leczonych w oddziale intensywnej terapii. Anestezjologia Intensywna Terapia 2010; 42: 94-96

Received: 19.06.2018

Accepted for publication: 28.08.2018

Otrzymano: 19.06.2018 r.

Zaakceptowano do publikacji: 28.08.2018 r.

\section{Adres do korespondencji:}

Address for correspondence:

Dr n.med. Małgorzata Kłósek

Katedra i Zakład Mikrobiologii i Immunologii

Wydział Lekarski z Oddziałem Lekarsko-Dentystycznym w Zabrzu

Śląski Uniwersytet Medyczny w Katowicach

Ul. Jordana 19, 41-808 Zabrze

e-mail:mklosek@sum.edu.pl

tel/fax: +48 322722554 